\title{
The Effect of Competitive Advantage, The Role of Information Technology on Revisit Intention in Nagari Tuo Pariangan: Tourist Satisfaction as an Intervening Variable
}

\author{
Dini Masly ${ }^{1, *}$ Yunia Wardi ${ }^{2}$
}

\author{
${ }^{1,2}$ Universitas Negeri Padang, Padang, Indonesia \\ *Email: dinimaslyy05@gmail.com
}

\begin{abstract}
This study aims to analyze the effect of competitive advantage and the role of information technology in Nagari Tuo Pariangan Tanah Datar District and tourist satisfaction as an intervening variable. This research is a causative research with PLS (Partial Least Square) analysis technique. The population in this study are all tourists who have visited the tourist attraction of Nagari Tuo Pariangan, both foreign and domestic tourists, with a total sample of 260 respondents. The results showed that there was a significant positive effect on compeitive advantage on tourist satisfaction, information technology on tourist satisfaction, competitive advantage on revisit intention, tourist satisfaction with revisit intention, competitive advantage on revisit intention through tourist satisfaction, and information technology on revisit intention through tourist satisfaction. The results also showed that there was no significant positive relationship between information technology on revisit intention.
\end{abstract}

Keywords: Revisit Intention 1, Tourist Satisfaction 2, Competitive Advantage 3, Information Technology 4.

\section{INTRODUCTION}

The tourism sector is ranked third in foreign exchange earnings after oil and gas and palm oil commodities, so that in 2009 , tourism was ranked third in foreign exchange earnings after oil and gas and palm oil commodities and is an important economic sector in Indonesia [1]. Added to the data in 2010, the number of foreign tourists coming to Indonesia amounted to more than 7 million people or grew by $10.74 \%$ compared to the previous year, and contributed foreign exchange to the country amounted to 7,603.45 million United States dollars [2]. In 2018 foreign tourist arrivals reached 15.8 million and contributed the largest foreign exchange to beat the oil and gas and palm oil sector [3].

West Sumatra is one of the tourism destinations that have great potential, one of the tourist objects in West Sumatra which has a unique attraction is the Nagari Tuo Pariangan. Nagari Tuo Pariangan is one of the nagari / villages in Tanah Datar Regency. Located on the slopes of Mount Merapi, Pariangan District, Tanah Datar Regency adjacent to the City of Serambi Mekkah Padang Panjang. The village area is about 2,749 hectares and has 6,012 inhabitants. The livelihood of the people is farming which is dominated by the rice sector. Nagari Tuo Pariangan has 4 jorong namely, Jorong Pariangan, Jorong Sikaladi, Jorong Padang Panjang, and Jorong Guguak.

In an effort to increase the number of visits and interest in tourism revisit in order to increase local revenue from the tourism sector, special handling and good management are needed so that the existing tourism assets become tourism potential in the form of service businesses, facility businesses, and management and strategies of an object tour. According to [3], revisiting interest is a behavior that arises as a response to an object that indicates the customer's desire to make a repeat purchase. The repurchase decision process is formed after the after-purchase stage. In the purchase cycle shows that there are two things that affect a customer to make a repurchase, namely post-purchase evaluation and the decision to repurchase. Customers consciously and unconsciously are in the after purchase stage, will evaluate the transaction that has been done. The level of customer satisfaction or dissatisfaction that will affect behavior. If the consumer is satisfied because of the good quality of service, he will show a great opportunity to make a repeat purchase. And satisfied 
customers will also tend to state good things about a tourist attraction to others [5].

This was confirmed by [6] that customer satisfaction created can provide several benefits including the establishment of a harmonious relationship between the service provider organization and its customers, providing a good basis for repurchasing and creating customer loyalty and forming a word of mouth recommendation (word-of-mouth ofmouth) that is profitable for the company In short, good service quality can be seen from the repurchase interest that arises in the customer. While consumers who are dissatisfied will react with negative actions such as silence, complaining, and even recommending negativity to others.

The main key in winning the competition is providing value and satisfaction to customers through the delivery of quality products and services.[7]. To design market offers that deliver more value than competitors who are trying to win the same market, companies must understand customers and develop strong relationships with customers. The offer is also called competitive advantage [8], where the company has by offering greater value to consumers than competitors can gain an advantage over competitors offers Companies need to understand competitors and customers through analysis to achieve these competitive advantages.

This means that the Nagari Tuo Pariangan tourist attraction needs to know the advantages it has to maintain competition and create sustainable tourism. Knowing the competitive advantage can make tourism activities even better because managers know what must be strengthened to win the competition and create sustainable tourism. According to [9], competitive advantage is an advantage obtained through the application of competitive strategies that aim to build a profitable and sustainable position against market forces that determine industrial competition.

The increasing human need to travel, making many tourist objects began to be managed seriously by the private sector and local government where the object is located. Not only natural attractions, artificial attractions also began to develop rapidly in accordance with community needs. one way to preform managing attractions is the role of information technology to reach a wider market.

One important role in tourism activities is the role of information technology. In the 4.0 revolution, technology was a major milestone in industrial activity. According toProf. Klaus Schwab, German worldrenowned economist, Founder and Executive Chair of the WEF who introduced the concept of the Industrial Revolution 4.0 in his book entitled "The Fourth Industrial Revolution" [10] explains the industrial revolution 4.0 has changed the lives and work of humans in a mental fundamentals. Unlike the previous industrial revolution, the 4th generation industrial revolution has a wider scale scope and complexity.

With the existence of good information technology, visitors will find it easier to access information about Nagari Tuo Pariangan tourism objects, this will certainly attract a return visit for consumers if the tourism object management can facilitate and utilize the information technology. The role of information technology that can facilitate and reach a broad market is very strategy to be developed in businesses is no exception in the Nagari Tuo Pariangan tourist attraction. If competitive advantage and information technology can provide satisfaction, it is expected to build loyalty towards tourists. Therefore, knowing competitive advantage and seeing the responses of tourists to the use of information technology can determine the position of the strength of the Nagari Tuo attraction in winning competition.

Based on this background, the researchers tested how the role of competitive advantage and information technology in influencing the interest in returning tourists with tourist satisfaction as an intervening variable. This research is very important because it provides an understanding of the level of competitive advantage and information technology in the tourist attraction of Nagari Tuo Pariangan can provide tourist satisfaction so that there is interest in revisiting and developing the potential for competitive advantage and the role of information technology in winning the market.

\subsection{Revisit Intention}

Repurchase interest is defined as purchase intention, which is a strong desire to repurchase [11] defines purchase intention as a person's mental state that reflects a plan to take several actions within a certain period of time. This definition is assumed to be a direct antecedent of behavior. Its application in research on the definition of purchases intention is that customers will make an action to buy back in the future as a direct response to post-purchase behavior within a certain period of time.

If the consumer is satisfied because of the good quality of service, he will show a great opportunity to make a repeat purchase. And customers who are satisfied will also tend to say good things about the tourist attraction to others [5]. This was confirmed by [6] that the creation of customer satisfaction can provide several benefits, including the relationship between service provider organizations and their customers being harmonious, providing a good basis for repurchasing and creating customer loyalty, and forming a word of mouth recommendation (word-ofmouth of-mouth) that is profitable for the company. 
Having a positive relationship is a special benefit of customer satisfaction revisit intention or repurchase interest, and have the potential to become a source of future income, especially through repurchasing, both cross-selling and up-selling [12]. Customer satisfaction can provide several benefits. includes a harmonious relationship between the customer and the company that provides a sound basis for repurchases and builds customer loyalty, and forms useful word of mouth recommendations for the company. Customer satisfaction also strengthens behavior towards the brand and most likely will lead to purchases of the same brand. In this study, the variable interest in repurchasing or revisiting interest can be formed from 3 indicators, namely:1)Plan for a return visit,2) Interest preference visits, 3) Interest of reference visits.

According to Timm, no business or organization can be successful without building customer satisfaction and loyalty. Timm describes the 5 elements of customer loyalty as follows:1) Satisfaction, that is, overall customer satisfaction. Low or erratic levels of satisfaction disqualify a company from gaining customer loyalty.2) Commitment, namely the customer's commitment to using e-ticketing in an ongoing relationship with the company. 3) Repeat purchase, the goal of the customer to become a repeat buyer. 4) Recommendation, is the customer's willingness to recommend the company to others. 5) Resistance namely the resistance of customers to turn to competitors.

\subsection{Tourist Satisfaction}

One measure of the performance of non-financial organizations that has a very significant contribution to the success of business organizational goals is customer satisfaction.[11] There are various conceptual definitions of customer satisfaction that have been used by previous researchers According to [14] in their research they have identified various conceptual definitions from the literature and from previous researchers about customer satisfaction Based on some of the conceptual definitions Giese et al concluded three main components in the definition of customer satisfaction: first, customer satisfaction is an emotional and cognitive response; both responses focused more on expectations, products, consumption and experiences; all three responses occur after consumption, after selection and are based on accumulated experience.

According to [15] explained that there are three indicators used to measure customer satisfaction variables, including:1) Overall satisfaction, 2) Confirmation of expectation, 3) Performance versus ideal.

According to the results of research conducted by [16] there is a significant and positive influence between consumer satisfaction with interest in revisiting undergraduate and graduate students at Western Australian universities, furthermore research conducted by [17] examined the effect of the quality of tourism services on visitor satisfaction and its impact on visitor loyalty.

H5: Tourist Satisfaction has a significant positive effect on revisit intention.

\subsection{Competitive Advantage}

[18] Describes competitive advantage as a condition in which a company can do something and another company cannot, or has something its competitors want.

[19] Stated that the discussion about competitive advantage in the literature tends to emphasize the competitive advantage of activities that generate added value by firms and organizations. For tourism purposes, competitive advantage can be related to natural resources such as climate, scenery, flora, fauna and others. Besides that, it is also related to tourism infrastructure (hotel chains, attractions and transportation networks), festivals and events, quality management, skills of the tourism sector workforce, government policies and others.

[20] State that the current context has forced tourism destination managers to seek innovative strategies and competitive advantages in achieving customer loyalty which in turn can increase the benefits of return visits and recommendations from customers. From the research conducted it can be concluded that innovation and competitive advantage can affect tourist loyalty and interest in return visits and recommendations for other customers.

According to [21] there are four factors that affect the national excellence of a country, these are: 1) Factor conditions. 2) Demand conditions. 3) Related and supporting industries. 4) Firms strategy, structure, and rivalry. Porter's Diamond Model can be applied at different levels (Alonso Almeida and Martin Castilla, 2009: 107): including at the national, regional and business levels.

Based on research conducted [22] there is a significant and positive relationship between Competitive Advantage and Consumer Satisfaction. This research is viewed by the indicators of innovation doffrentiation and market diffrentiation. Research conducted by [20] resulted in the conclusion that the competitive advantage of a tourist attraction is one of the determinants of customer satisfaction. Based on the research results above, it can be concluded that the factors that influence visitor satisfaction, one of which is the competitive advantage of a tourist attraction.

H1: Competitive advantage has a significant effect on tourist satisfaction 
H3: Competitive advantage has a significant positive effect on the revisit intention

H6: Competitive advantage has a significant positive effect on revisit intention through tourist satisfaction

\subsection{Information Technology}

According to ITAA in Sutarman [23] the definition of Information Technology (IT) is a study design development, implementation support or management of computer-based information systems especially software and software applications computer hard.

Understanding information technology according to [24] is technology is a computer network consisting of various components of information processing using various types of hardware, software, data management, and information network technology. While Understanding of information technology according to [25] is information technology can run effectively if members in the organization can use information technology properly and is very important for individuals.

[23] suggested several reasons why the application and management of information technology is an important part: first, the increasing complexity of management tasks; second, the international economy (globalization); third, the need for faster response times; and fourth, pressure due to business competition.

The advantages of applying information technology according to [23] are as follows: first Speed (Speed) Computers can do complex calculations in seconds very fast, much faster than humans can do. Second Consistency The results of processing are more consistent and do not change because the format (shape) is standard even though it is done repeatedly, while humans find it difficult to produce exactly the same. Third Accuracy (Precision) Computers are not only fast, but also more accurate and precise (precision). The computer can detect very small differences, which cannot be seen by human ability, and can also perform difficult calculations. Fourth Reliability (Reliability) What is produced is more reliable than what is done by humans. Errors are less likely to occur when using a computer.

Based on research conducted by [26], the results of the study stated that there was a significant and positive influence on the role of information technology on satisfaction. Then [27] also conducted research on the effect of information technology with Perceived usefulness variables, perceived ease of use, from this study it was stated that there was a significant positive relationship of the variables studied. [28] Who conducted research on exploring technology satisfaction, from the results of their research again emphasized that there is a significant positive relationship with information technology on loyalty through customer satisfaction.
H2: Information technology has a significant positive effect on tourist satisfaction

H4: Information technology has a significant positive effect on revisit intention

H7: Information technology has a significant positive effect on revisit intention through tourist satisfaction.

\section{METHODS}

\subsection{Samples and Data}

The population in this study were visitors who were over 17 years of age and had been to the tourist attraction of Nagari Tuo Pariangan, consisting of domestic tourists and foreign tourists. The technique used in this study is a non probability sampling technique, with a type of accidental sampling. The sample size was taken as much as 260 samples with consideration of statistical adequacy of the sample to obtain a power of 0.8 with an alpha of 0.05 , so a minimum sample of 5 times to 20 items were observed (Hair, Anderson, Babin, \& Black, 2010: 12). The results of the distribution of research questionnaires who made it back as many times 354fruit with a rate of return (response rate) of $73.4 \%$. So the questionnaires used in the analysis in this study were 260 questionnaires and the remaining $26.6 \%$ were not feasible because they did not meet the requirements.

Table 1 shows a descriptive analysis of the demographic characteristics of the respondents to provide information on gender, age, and occupation.

Table 1

Sample characteristics.

\begin{tabular}{lcc}
\hline Variable & Frequency & $\begin{array}{c}\text { Percentage } \\
(\%)\end{array}$ \\
\hline Gender & 103 & 39.6 \\
Male & 157 & 60.4 \\
Female & & \\
Age (years old) & & \\
$\quad$ 17-30 & 131 & 50.4 \\
$\quad 31-40$ & 108 & 41.5 \\
$\quad 41-50$ & 17 & 6.5 \\
$>$ 50 & 4 & 1.5 \\
$\quad$ Work & & \\
Employees (PNS / TNI / & 62 & 23.8 \\
POLRI / BUMN / & & 35.8 \\
Entrepreneur & 93 & 23.1 \\
Student & 60 & 17.3 \\
Others (Others) & 45 & \\
\hline
\end{tabular}

Furthermore, this study will be analyzed using the PLS-SEM approach. In this study, we used Smart PLS version 3 to test the conceptual framework proposed in 
the hypothesis. Analyzes are presented in a transparent and sequential manner, allowing clarity in the conceptual framework and results.

\subsection{Measurement}

The scale used in this study uses a 5-point Likert scale with strongly disagree (1) to strongly agree (5). The 5-point Likert scale is used because it is easy to respond to and requires less completion time when compared to open questions (Arikunto, 2006).

\section{RESULTS AND DISCUSSION \\ 3.1. Result and release}

To test the hypothesis this study uses PLS-SEM based on primary data collected to obtain a direct relationship between competitive advantage and information technology on revisiting interest and satisfaction as an intervening. SmartPLS 3.0 is used to analyze structural equation models. The algorithm estimates the measurement of the model by explaining the variance of the dependent construct. In the first step, the construction score is estimated. Then, the final estimate of the outer loading is also calculated using the structural model of the path coefficient, which produces the $\mathrm{R} 2$ value of the endogenous latent variable.

Table II provides descriptive statistics of the observed respondents. Revisit interest is considered the highest average score 4,12 then tourist satisfaction with an average value3.96 furthermore competitive advantage with an average score of 4.09 , followed by information technology with an average score of 3.84.

There are three main results for Smart PLS: outer loading for model measurements, path coefficients for structural models and R2 values for latent variables. Assessment of the measurement model also involves the reliability of the composite test for internal consistency, the reliability of each indicator and the mean of variance extracted to check for convergent validity.

The focus of the first step is on the confirmation of valid and reliable construct steps. Hypothesis testing involving structural relationships between constructs will be reliable if the measurement model describes how the constructs meet the standards of validity and reliability. Cronbach alfa shows that the latent variable has a value greater than 0.7 which indicates high reliability based on the relationship between the observed variable indicators. The composite reliability test value is greater than 0.7 which indicates a high level of reliability and is considered satisfactory.

The validity was set convergent, taking into account the mean variance extracted and the external loading. The results show the standard offloading is greater than 0.649 , which indicates the community accepted level (see Appendix). AVE value is higher than 0.5 which indicates the level of public acceptance.
These values indicate that the constructs explain more than half the variance of the indicator.

(Table II).

\begin{tabular}{|c|c|c|c|c|}
\hline & $\begin{array}{l}\text { Cronbach's } \\
\text { Alpha }\end{array}$ & rho_A & $\begin{array}{l}\text { Composite } \\
\text { Reliability }\end{array}$ & $\begin{array}{c}\text { Average } \\
\text { Variance } \\
\text { Extracted } \\
(\text { AVE) }\end{array}$ \\
\hline $\begin{array}{l}\text { Tourist } \\
\text { Satisfaction }\end{array}$ & 0.822 & 0.824 & 0.883 & 0.653 \\
\hline $\begin{array}{l}\text { Competitive } \\
\text { advantage }\end{array}$ & 0.891 & 0.893 & 0.911 & 0.507 \\
\hline $\begin{array}{l}\text { Revisit } \\
\text { Intention }\end{array}$ & 0.738 & 0.739 & .851 & .656 \\
\hline \multirow[t]{2}{*}{$\begin{array}{l}\text { Information } \\
\text { Technology }\end{array}$} & 0.866 & 0.869 & .909 & 0.714 \\
\hline \multirow{2}{*}{\multicolumn{3}{|c|}{$\begin{array}{l}\text { Tourist Satisfaction -> revisit } \\
\text { intention }\end{array}$}} & FP & \\
\hline & & & 2,466 & \\
\hline \multicolumn{3}{|c|}{$\begin{array}{l}\text { Competitive advantage -> } \\
\text { tourist satisfaction }\end{array}$} & 1,669 & \\
\hline \multicolumn{3}{|c|}{$\begin{array}{l}\text { Competitive advantage -> } \\
\text { revisit intention }\end{array}$} & 2,452 & \\
\hline \multicolumn{3}{|c|}{$\begin{array}{l}\text { Information technology -> } \\
\text { tourist satisfaction }\end{array}$} & 1,669 & \\
\hline \multicolumn{3}{|c|}{$\begin{array}{l}\text { Information technology-> } \\
\text { revisit ntention }\end{array}$} & 1,862 & \\
\hline
\end{tabular}

The second step looks at the assessment of the structural model results. Before conducting an analysis, it is important to identify multicollinearity problems. Table III shows that the VIF value of the constructs is below the threshold of 5, which indicates that the collinearity between constructs is not a problem in the structural model. Hence, Figure 1 explains that the R2 value of return visit interest is 0.542 and the $\mathrm{R} 2$ of visitor satisfaction is 0.595 , which indicates that all the combined effects of the exogenous variables are latent on return visit interest and tourist satisfaction. $\mathrm{R} 2$ value shows the moderate level of prediction accuracy.

Table IV shows that the PLS-SEM bootstrap can provide evidence that the $\mathrm{t}$-value for each construct is greater than the critical value, indicating that all coefficients are significant at the 5 percent level. The PLS-SEM algorithm shows the hypothesized relationship between constructs except for the relationship between information technology and reinterpretation. The path coefficient of +1 indicates a strong positive relationship (Figure 1). The results show that the coefficient varies from 0.279 to 0.563 . 


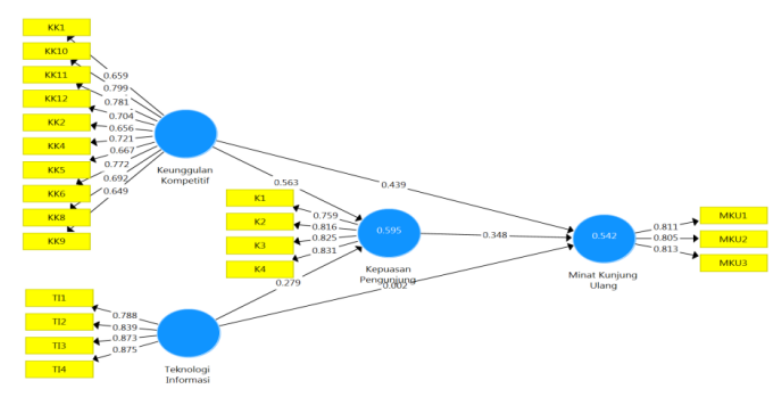

\begin{tabular}{|c|c|c|c|c|c|c|}
\hline Hypothesis & $\begin{array}{c}\text { Original } \\
\text { Sample } \\
(\text { O) }\end{array}$ & $\begin{array}{c}\text { Sample } \\
\text { Mean } \\
\text { (M) }\end{array}$ & $\begin{array}{c}\text { Standar } \\
\text { d } \\
\text { deviatio } \\
\text { n } \\
\text { (STDEV } \\
\text { ) }\end{array}$ & $\begin{array}{c}\mathbf{T} \\
\text { Statistics } \\
(\mid \mathbf{O} / \\
\text { STDEV } \\
\mid)\end{array}$ & P Values & $\begin{array}{c}\text { Informati } \\
\text { on }\end{array}$ \\
\hline \multicolumn{7}{|c|}{ Direct Influence } \\
\hline $\begin{array}{l}\text { Competitive } \\
\text { Advantage - } \\
\text { > Visitor } \\
\text { Satisfaction }\end{array}$ & 0.563 & 0.565 & 0.050 & 11,228 & 0,000 & $\begin{array}{l}\text { Receiv } \\
\text { ed }\end{array}$ \\
\hline $\begin{array}{l}\text { Information } \\
\text { Technology - } \\
\text { > Visitor } \\
\text { Satisfaction }\end{array}$ & 0.279 & 0.278 & 0.055 & 5,084 & 0,000 & $\begin{array}{l}\text { Receiv } \\
\text { ed }\end{array}$ \\
\hline $\begin{array}{l}\text { Competitive } \\
\text { Advantage - } \\
\text { > Revisiting } \\
\text { Interest }\end{array}$ & 0.635 & 0.638 & 0.059 & 10,685 & 0,000 & $\begin{array}{l}\text { Receiv } \\
\text { ed }\end{array}$ \\
\hline $\begin{array}{l}\text { Information } \\
\text { Technology - } \\
\text { > Revisiting } \\
\text { Interest }\end{array}$ & 0.099 & 0.096 & 0.066 & 1,497 & 0.135 & $\begin{array}{l}\text { Rejecte } \\
\mathrm{d}\end{array}$ \\
\hline $\begin{array}{l}\text { Visitor } \\
\text { Satisfaction - } \\
\text { > Revisiting } \\
\text { Interest }\end{array}$ & 0.348 & 0.350 & 0.080 & 4,354 & 0,000 & $\begin{array}{l}\text { Receiv } \\
\text { ed }\end{array}$ \\
\hline
\end{tabular}

\begin{tabular}{|l|l|l|l|l|l|l|}
\hline \multicolumn{7}{|c|}{ Indirect Effect (Mediation Effect) } \\
\begin{tabular}{|l} 
Competitive \\
Advantage-> \\
$\begin{array}{l}\text { Visitor } \\
\text { Satisfaction- } \\
\text { > Revisiting } \\
\text { Interest }\end{array}$
\end{tabular} & 0.196 & 0.199 & 0.052 & 3,758 & $\mathbf{0 , 0 0 0}$ & $\begin{array}{l}\text { Receiv } \\
\text { ed }\end{array}$ \\
\hline $\begin{array}{l}\text { Information } \\
\text { Technology- } \\
>\text { Visitor } \\
\text { Satisfaction- } \\
>\text { Revisiting } \\
\text { Interest }\end{array}$ & 0.097 & 0.097 & 0.027 & 3,584 & $\mathbf{0 , 0 0 0}$ & \\
\hline
\end{tabular}

Table IV the effect of competitive advantage on tourist satisfaction as indicated by a positive value and a p-value $<0.05$, namely 0.000 this indicates that $\mathrm{H} 1$ is accepted the influence of information technology on tourist satisfaction as indicated by a positive value and a p-value $<0.05$, namely 0.000 this indicates that $\mathrm{H} 2$ is accepted. Then,the effect of competitive advantage on interest in revisiting is indicated by a positive value and a p-value $<0.05$, namely 0.000 . This shows that $\mathrm{H} 3$ is accepted.The influence of information technology on interest in revisiting is indicated by a p-value> 0.05 , namely 0.135 . this shows that $\mathrm{H} 4$ is rejected. The influence of tourist satisfaction on the interest in revisiting is indicated by a positive value and a p-value $<0.05$, namely 0.000 . This shows that $\mathrm{H} 5$ was received.the effect of competitive advantage on interest in revisiting through tourist satisfaction as indicated by a positive value and a p-value $<0.05$, namely 0.000 . This indicates that $\mathrm{H6}$ is accepted.the influence of information technology on interest in revisiting through tourist satisfaction as indicated by a positive value and a p-value $<0.05$, namely 0.000 This indicates that $\mathrm{H} 7$ is accepted.

Based on the results, there is a strong tendency in empirical studies that competitive advantage and information technology have a significant impact on interest in customer visits and satisfaction. Either directly or indirectly. The exception is the information technology variable on the interest in revisiting which does not have a significant influence. This study shows that if the respondent considers that the tourist attraction of Nagari Tuo Pariangan has a competitive advantage in satisfying tourists, which has an impact on the interest in revisiting and the role of information technology can provide a sense of satisfaction but has not been able to attract the interest of revisiting tourists. However, if through satisfaction it has a significant positive effect on interest in returning to visit This study supports previous research by Fyall,

\section{CONCLUSION}

Competitive advantage has a positive and significant effect on tourist satisfaction at the Nagari Tuo Pariangan tourist attraction. This means that the better the competitive advantage in a tourist attraction can increase tourist satisfaction. The opposite occurs when the value of competitive advantage on a tourist attraction decreases.This research is in line with that conducted by Wen-Yu Tsao, there is a significant and positive relationship between Competitive Advantage and Consumer Satisfaction.

Information technology has a positive and significant effect on tourist satisfaction at the Tuo Pariangan tourist attraction. This means that the better information technology on a tourist attraction can increase tourist satisfaction. The opposite happens when the value of information technology on a tourist attraction decreases.From the results of research conducted by Rukia Vandyck, from the results of the study it was stated that there was a significant and positive influence on the role of information technology on satisfaction, so this research is in line with that conducted by Rukia Vandyck .

Competitive advantage has a positive and significant effect on the revisit intention the tourist attraction of Nagari Tuo Pariangan. This means that the better the competitive advantage in a tourist attraction can increase the revisit intention. The opposite occurs when the value of competitive advantage on a tourist attraction decreases.This research is in line with that conducted by Fyall, Callod and Edwards . 
Information technology does not have a positive and significant effect on revisit intention the tourist objects of Nagari Tuo Pariangan. This means that the worse the information technology on a tourist attraction cannot increase the revisit intention. The opposite happens when the value of information technology in a tourist attraction improves. This research contradicts that conducted by Cristina Calvo et al. which states that there is a significant positive relationship in exploring technology satisfaction which will build consumer loyalty.

Tourist satisfaction has a positive and significant effect on the revisit intention the Nagari Tuo Pariangan. This means that the better tourist satisfaction in a tourist attraction can increase revisit intention. The opposite occurs when the value of tourist satisfaction on a tourist attraction decreases. This research is in line with that conducted by Faruk Anıl Konuk which states that there is a significant positive influence between customer satisfaction and customer loyalty.

Competitive advantage on revisit intention through tourist satisfaction has a positive and significant effect. This means that the higher the value of competitive advantage, the more revisit intention the tourist attraction of Nagari Tuo Pariangan through tourist satisfaction.Ana Maria et al., in a study discussing the competitive advantages of sustainable rural tourism in Spain, that there is a significant positive relationship with loyalty through tourist satisfaction.

Information technology on revisit intention through tourist satisfaction has a positive and significant effect. This means that the higher the value of information technology, the more revisit intention Nagari Tuo Pariangan attractions through tourist satisfaction.This study is in line with what was done by Cristina Calvo, that there is a significant positive relationship between information technology on loyalty through customer satisfaction. Ida Ayu et al., also stated the same thing that technology can build consumer loyalty through customer satisfaction.

\section{AUTHORS' CONTRIBUTIONS}

The first author acts as a researcher in this study as well as a writer. The authors have conducted a lot of literature studies on the topic of related research. And the second author acts as a supervisor in research and article writing. the second author has provided many corrections and inputs in this research

\section{ACKNOWLEDGMENTS}

Praise and thanksgiving the author for the presence of Allah SWT for His mercy, blessings, and gifts so that the author can complete the task entitled "The Effec of Competitive influence, the role of information technology on revisit intention in Nagari Tuo Pariangan: tourist satisfaction as an intervening variable".

The author also wants to thank parents who have supported the author until this moment. to the supervisor who has provided input to the author. To UNP staff who have helped a lot in the administrative process in preparing the thesis and also to friends in Magister Manajemen. Thank you

\section{REFERENCES}

[1] Republika.co.id. Pariwisata ditargetkan jadi penyumbang devisa terbesar. M Nursyamsi. 2017

[2] Indonesia-investment.com. Industri Pariwisata Indonesia. 2016

[3] Portalnawacita.com. 5 tahun terakhir, rerata pertumbuhan kunjungan wisatawan Mancanegara 14\%. Gery. 2019

[4] Husein, Umar. Research Methods for Service Consumer Behavior. Jakarta: Ghalia Indonesia. 2003

[5] Kotler,Philip. Manajemen Pemasaran. Edisi Bahasa Indonesia jilid satu. Jakarta: Prentice Hall. 1997.

[6] Tjiptono, Fandy. Marketing strategy. Yogyakarta: Publisher Andi. 2002.

[7] Tjiptono, Fandy. Marketing Strategy, Third Edition. Andi, Yogyakarta. 2008.

[8] Kotler, Philip. Marketing Management. Thirteen Indonesian edition. Volume 1 and 2. Jakarta: Erlangga. 2010.

[9] Lancaster, L.C. dan Stillman, D. When Generations Collide. New York: Harper Business. 2002.

[10] Schwab, Klaus. The Global Competitiveness Report 2016-2017. Geneva: World Economic Forum. Diunduh pada 09 Oktober 2016. Tersedia pada https://www.weforum.org. 2016.

[11] R, Basiya and Rozak, Hasan Abdul. Quality of Tourist Attraction, Satisfaction, and Intention of Returning Foreign Tourists in Central Java. Journal of Tourism Dynamics, Vol. XI No.2, p. 112. 2012.

[12] Tjiptono, Fandy and Chandra, Gregory. Service Quality and Satisfaction. Yogyakata: Publisher Andi. 2005

[13] Assael, H. Consumer Behaviour and Marketing Action. Boston: Kent Publishing. 1995.

[14] Giese dan Cote. Menentukan kepuasan pelanggan. Washington: Washington State University. 2000.

[15] Shi, Y., Prentice, C., \& He, W. Linking service quality, customer satisfaction and loyalty in casinos, does membership matter? International 
Journal of Hospitality Management, 40, 8191.https://doi.org/10.1016/j.ijhm.2014.03.013. 2014

[16] Vanessa A. Quintal Aleksandra Polczynski. Factors influencing tourists'revisit intentions. 2010.

[17] CHI, CGQ \& QU, H. Examining structural relationships of destination image, tourist satisfaction and destination loyalty: An integrated approach. Tourism Management, 29,624-636. 2008.

[18] David, Fred R. Strategic Management. Book 1, Tenth Edition. Jakarta: Four Salemba. 2006.

[19] Dwyer, L. \& C. Kim. Destination Competitiveness: Determinants and Indicators. Current Issues in Tourism, Vol. 6, No. 5, pp. 301310. 2003.

[20] Fyall, A; Callod, C; Edwards, B. Relationship Marketing: The Challenge for Destinations. Annals of Tourism Research, Vol. 30, No. 3, 2003, 644659. 2003.

[21] Porter,Michael,E. Strategi Bersaing (Competitive strategy). Tanggerang: Karisma publishing group. 2008.

[22] Tsao, Wen-Yu. Enchancing competitive advantages: The contribution of mediator and moderator on stickiness in the LINE. Journal of Retailing and Consumen Services, 21(6), 933-941. Doi:10.1016/j.jretconser.2014.08.011. 2014.

[23] Sutarman. Introduction to information technology. Jakarta: Earth Literacy. 2009.

[24] O'brien, James A., Marakas, George M. Management Information Systems, Eighth Edition. New york: The McGraw-Hill Companies, Inc. 2008 .

[25] Ike Rachmawati Kusdyah. Manajemen Sumber Daya Manusia, Yogyakarta: ANDI. 2008.

[26] Vandyck, Rukia. The Impact Information Technology on Customer Satisfaction at Social Security and National Insurence Trust. 2016.

[27] Wheelen \& Hunger. Strategic Management And Business Policy, Pearson Prentice Hall, New Jersey.2004.

[28] Cristina Calvo, Pierre Levy dan Mangin. The role of Consumer Trust on Loyalty and purchase Intention. 2016. 